\title{
Conceptions of Autonomy in Language Learning from a Cultural Perspectives Using Q Methodology
}

\author{
Siti Maftuhah Damio ${ }^{a}$, Pn Hamimah Hashim ${ }^{b}$
}

\begin{abstract}
The adoption of Autonomy in Language Learning (ALL) is claimed to be beneficial to learners learning a second or foreign language. It is asserted that through ALL, learners are able to make better progress and continue to learn and acquire the target language even after the formal learning is over. Nonetheless, the consensus on what ALL entails and its universal applicability is still questioned. There are debates on the possibility of ALL paradigm shifts due to cultural perspectives. In addressing this issue, an investigation of the conception of ALL among Malay trainee teachers of English as a Second Language in Malaysia was carried out. The objective was to explore the participants' subjective viewpoints of ALL. In an attempt to do this systematically, Q Methodology was chosen. This method allows for the researcher to have insights and identify the participants' conceptions of ALL. The result showed that the trainee teachers conceptualized interdependence as well as empowerment and flexibility as important in ALL. The finding corroborate with the notion of students constructing knowledge from experience, which may have its basis on cultural background.
\end{abstract}

\section{Introduction}

Being an English as a Second Language speaker in an environment where conflicting views on the importance of English are constantly debated is challenging. This is the case in Malaysia. On the one hand, the country expects its people to be proficient in English yet some segments of society ridicule those who communicate in the language. Manoeuvring through this intricate environment requires skills which need to be nurtured and developed. Being an autonomous second

\footnotetext{
a Faculty of Educaiton, University Teknologi MARA

b Faculty of Educaiton, University Teknologi MARA
} 
language learner might prove to be beneficial as autonomy encompasses the different skills needed in becoming a proficient learner and user of English, as well as understanding the appropriate context to use it. Our aim in this article is, thus, to examine the conceptions surrounding the concept of Autonomy in Language Learning (ALL) in a Faculty of Education in a public university in Malaysia. Specifically, this article addresses this research question: What are the varieties of perspectives deployed in the representation of Autonomy in Language Learning (ALL) among Malay trainee English teachers?

\section{Literature Review}

The importance of autonomy in language learning has led to an extensive literature and progression and refinement of the concept. This is shown by the definition and redefinition of the concept. One problem is with the terminology used in discussing autonomy. Pemberton (1996: p. 2) gave two arguments related to the issue of terminology. He argued that;

"the first problem is that ... different terms are often used to refer to the same thing. ... The second, related, problem is that the same term is often used to mean different things".

Autonomy in language learning is and has been associated with other terms like learner independence, self-directed learning (Benson 2011: p. 37; learning that is carried out under the learner's own direction), self-regulated learning (Pintrich, 1995: p. 5; the active, goal directed self-control behaviour, motivation and cognition for academic tasks by an individual student), self-access learning, open learning (Peschel, 2002: p. 3); allowing learners for self-determined, independence and interest-guided learning,), selfinstruction (Dickinson, 1987: p. 1; deciding to learn without a teacher means that the learner, with others or alone, is working without the direct control of a teacher), distance learning and self-paced learning. According to Benson (2006, p. 1);

"these terms basically describe various ways and degrees of learning by yourself, whereas autonomy refers to abilities and attitudes (or whatever we think the capacity to control your own learning consists of). The point is, then, that learning by yourself is not the same thing as having the capacity to learn by yourself." 
Benson's (2006) description pointed that the concept is more learner-oriented. It is therefore pertinent for authors and researchers to define autonomy in the context that they are working on.

The most widely quoted definition of autonomy in language learning is Holec's (1980, p. 3);

"the ability to take charge of one's own learning. ... This ability is not inborn but must be acquired either by 'natural' means or (as most often happens by formal learning, in a systematic, deliberate way".

It is indeed an ability, a power or capacity to do something and not a type of conduct or a behaviour. In order 'to take charge of one's own learning', the learner has to take the responsibility for making decisions regarding the learning like what, how, when to learn the language. This serves as a starting point in exploring the concept, of which many other emerging definitions follow.

Oxford (2000) noted that the different definitions and understandings of autonomy suggest that the theoretical framework for autonomy in language learning needs further refinement. Huang (2009, p. 8), however, suggested that there are areas of agreement among authors and researchers in the field that autonomy should be viewed from multiple perspectives, autonomy is a teacher's and learner's right, there are degrees of autonomy, the development of autonomy implies collaboration and interdependence, rather than learners working in isolation, and the concept of autonomy can accommodate different interpretations and is universally appropriate.

\section{Methodology}

This study explores how ALL is conceptualized among Malay trainee teachers in a public university as stated in the research question:

What are the varieties of perspectives deployed in the representation of Autonomy in Language Learning (ALL) among Malay trainee English teachers?

In order to address the research question, the methods of data collection employed are qualitatively inclined, involving Q-methodology and interviews. 
Q Methodology was "designed expressly to explore the subjective dimension of any issue towards which different points-of-view can be expressed" (Stenner, Watts \& Worrell, 2008, p. 215). The development of $\mathrm{Q}$ arose from a perceived need to bring a scientific framework to the world of subjectivity, which Brown (1993: p. 94) referred to as the "basis for a science of subjectivity". This is achieved by involving the use of factor analytic technique for grouping like-minded individuals.

Q Methodology involves seven steps as summarised in Table 1. It is not the intention of this paper to comprehensively present the steps but enough is covered to introduce what Q methodology is.

Table 1: Seven steps of $Q$ Methodology

\begin{tabular}{|l|l|l|}
\hline Step & Activity & Description \\
\hline 1 & $\begin{array}{l}\text { Defining and build- } \\
\text { ing the concourse }\end{array}$ & $\begin{array}{l}\text { Defining the concourse is } \\
\text { the first step. The 'concourse' } \\
\text { is the collection of possible } \\
\text { statements people make about the } \\
\text { topic. }\end{array}$ \\
\hline 2 & $\begin{array}{l}\text { Developing the Q } \\
\text { Set }\end{array}$ & $\begin{array}{l}\text { The second step is the develop- } \\
\text { ment of the Q set. A Q set is "a } \\
\text { purposive selection of state- } \\
\text { ments" (Brown, 2003: p. 2) drawn } \\
\text { from the concourse. The next } \\
\text { item to prepare is a Q-grid (score } \\
\text { sheet) and the Condition of In- } \\
\text { structions }\end{array}$ \\
\hline
\end{tabular}




\begin{tabular}{|l|l|l|}
\hline 3 & $\begin{array}{c}\text { Selection of the P } \\
\text { Set }\end{array}$ & $\begin{array}{l}\text { The third stage involves the } \\
\text { selection of the Q participants. } \\
\text { These participants are referred } \\
\text { to as the 'P-set'. The selection of } \\
\text { Q participants is not randomly } \\
\text { done, rather, participants are } \\
\text { deliberately selected to be as } \\
\text { heterogeneous as possible. Q } \\
\text { methodology tends to involve "a } \\
\text { structured sample of respondents } \\
\text { who are theoretically relevant to } \\
\text { the problem under consideration; } \\
\text { for instance, persons who are ex- } \\
\text { pected to have a clear and distinct } \\
\text { viewpoint regarding the problem" } \\
\text { (Exel \& Graaf, 2005: 6). }\end{array}$ \\
\hline 4 & $\begin{array}{l}\text { Conducting the } \\
\text { Sorting }\end{array}$ & $\begin{array}{l}\text { The Q Sorting is when the indi- } \\
\text { vidual participant ranks the Q } \\
\text { statements into a forced quasi- } \\
\text { normal distribution (a pre-set } \\
\text { pattern grid with a scale labelled } \\
\text { 'most like what I think', 'neutral' } \\
\text { and 'least like what I think' }\end{array}$ \\
\hline 5 & Post Q Interview & $\begin{array}{l}\text { Participants were asked to explain } \\
\text { the reasons behind the placements } \\
\text { of the cards on the grid. }\end{array}$ \\
\hline & $\begin{array}{l}\text { A by-person correlation and } \\
\text { factor analytic technique was } \\
\text { employed to analyse the 31 com- } \\
\text { pleted Q Sorts. }\end{array}$ \\
\hline & Analysis & \\
& &
\end{tabular}




\begin{tabular}{|l|l|l|}
\hline 7 & Interpretation & $\begin{array}{l}\text { The interpretation of factors, ac- } \\
\text { cording to Webler, Danielson and } \\
\text { Tuler (2007: p. 27) is when the } \\
\text { researcher "writes a description } \\
\text { of the perspectives that the factor } \\
\text { represents". This is achievable by } \\
\text { comparing and contrasting the } \\
\text { positing of the statements in the } \\
\text { reconstructed Q sorts that repre- } \\
\text { sent each factor. }\end{array}$ \\
\hline
\end{tabular}

\section{Empirical Result}

The use of factor analytic technique in analysing the data in $\mathrm{Q}$ methodology resulted in four factors. This is Step 6 in the seven steps of Q Methodology (Table 1). Though there are four pertinent factors, only two (2) of the factors are discussed in this article. Table 2 shows Factor Q-Sort Values for Statements in each of the four factors sorted by Consensus vs. Divergence. These values are used in the explanation on the interpretation of the two factors in the following sections. The (S32: 5) refers to Statement 32 ranking +5 from the rank of +5 to -5 .

Table 2: Factor Q-Sort Values for Statements sorted by Consensus vs. Divergence

\begin{tabular}{|c|c|c|c|c|}
\hline $\begin{array}{l}22 \text { ALL is when learners improve their language } \\
\text { learning within the institution }\end{array}$ & -3 & -4 & -2 & -2 \\
\hline $\begin{array}{l}20 \text { ALL involves learners' active participation in } \\
\text { planning and evaluating their own learning }\end{array}$ & 4 & 3 & 3 & 4 \\
\hline $\begin{array}{l}35 \text { ALL is having the skills to be a responsible lan } \\
\text { guage learner }\end{array}$ & 1 & 0 & 1 & 2 \\
\hline $\begin{array}{l}4 \text { ALL only involves the use of authentic (not } \\
\text { educational) materials }\end{array}$ & -2 & -1 & -3 & -4 \\
\hline $\begin{array}{l}26 \text { ALL is having the skills to be a flexible } \\
\text { language learners }\end{array}$ & 3 & 2 & 2 & 2 \\
\hline
\end{tabular}




\begin{tabular}{|c|c|c|c|c|c|}
\hline 10 & $\begin{array}{l}\text { ALL involves accepting that freedom is not } \\
\text { absolute }\end{array}$ & -1 & -2 & -2 & -2 \\
\hline 6 & $\begin{array}{l}\text { ALL can take place in a teacher-directed } \\
\text { context }\end{array}$ & -4 & -4 & -3 & -3 \\
\hline 39 & ALL is only applicable to Western setting & -5 & -4 & -5 & -5 \\
\hline 16 & $\begin{array}{l}\text { ALL involves self-access language learning in } \\
\text { the Self-Access Centre (SAC) }\end{array}$ & -1 & 1 & -1 & -1 \\
\hline 15 & $\begin{array}{l}\text { ALL is about empowering learners to improve } \\
\text { their conditions }\end{array}$ & 1 & 2 & 1 & 3 \\
\hline 17 & $\begin{array}{l}\text { ALL involves using new technologies (e.g. } \\
\text { computer-assisted) }\end{array}$ & 0 & -1 & 0 & 0 \\
\hline 29 & $\begin{array}{l}\text { ALL involves acquiring skills for independent } \\
\text { learning }\end{array}$ & 0 & 3 & 2 & 1 \\
\hline 36 & $\begin{array}{l}\text { ALL is when learners improve their language } \\
\text { learning outside the institution }\end{array}$ & 2 & 1 & 4 & 1 \\
\hline 27 & $\begin{array}{l}\text { ALL is a steady state achieved by successful } \\
\text { language learner }\end{array}$ & -1 & -1 & 1 & -2 \\
\hline 21 & $\begin{array}{l}\text { ALL is having the skills to be a proficient } \\
\text { language learner }\end{array}$ & 0 & 1 & 3 & -1 \\
\hline 34 & ALL can only occur outside formal classroom & -4 & -3 & -4 & -5 \\
\hline 24 & $\begin{array}{l}\text { ALL involves teachers giving instructions to } \\
\text { learners on what to do }\end{array}$ & -5 & -4 & -4 & -3 \\
\hline 12 & $\begin{array}{l}\text { ALL involves taking responsibility for your } \\
\text { own learning }\end{array}$ & 1 & 4 & 5 & 1 \\
\hline 5 & $\begin{array}{l}\text { ALL involves the universal human } \\
\text { characteristics of independence and } \\
\text { interdependence }\end{array}$ & 1 & 0 & 3 & 0 \\
\hline 9 & ALL involves using self-instructional materials & -2 & 1 & -2 & 0 \\
\hline & $\begin{array}{l}\text { Memorising words and sentences is an } \\
\text { example of }\end{array}$ & -4 & -3 & -1 & -4 \\
\hline 14 & $\begin{array}{l}\text { ALL is a willingness to act independently and } \\
\text { in cooperation }\end{array}$ & 4 & 0 & 5 & 2 \\
\hline 30 & ALL is having effective learning strategies & 2 & 0 & 4 & 3 \\
\hline 28 & ALL is communicative language learning & 0 & -2 & 0 & 1 \\
\hline 31 & $\begin{array}{l}\text { ALL is a constant negotiation between the self } \\
\text { and the social }\end{array}$ & 2 & -2 & -1 & -1 \\
\hline
\end{tabular}




\begin{tabular}{|ll|l|l|l|l|}
\hline 13 & $\begin{array}{l}\text { ALL involves putting a lot of effort into } \\
\text { language learning }\end{array}$ & 0 & -2 & 4 \\
\hline 2 & $\begin{array}{l}\text { ALL involves learners having some control } \\
\text { over their learning }\end{array}$ & 1 & 1 & 0 & 5 \\
\hline 23 & $\begin{array}{l}\text { ALL involves the development of the learner's } \\
\text { sense of individuality }\end{array}$ & -1 & 2 & 4 & 0 \\
\hline 25 & $\begin{array}{l}\text { ALL is present in different degrees at different } \\
\text { times }\end{array}$ & 3 & -1 & 1 & -2 \\
\hline 3 & $\begin{array}{l}\text { All promotes the freedom of the learner } \\
37\end{array} \begin{array}{l}\text { ALL development is slowed when there is } \\
\text { teacher intervention }\end{array}$ & -3 & 0 & -4 & -3 \\
\hline 18 & $\begin{array}{l}\text { ALL takes place both inside and outside of the } \\
\text { classroom }\end{array}$ & 5 & 0 & 2 & 2 \\
\hline 19 & $\begin{array}{l}\text { ALL often occurs in social groups (family, } \\
\text { clubs or community" }\end{array}$ & 2 & -1 & -3 & 0 \\
\hline 1 & $\begin{array}{l}\text { ALL is when language learners enjoy a high } \\
\text { degree of freedom }\end{array}$ & 3 & 3 & 0 & -1 \\
\hline 11 & $\begin{array}{l}\text { ALL involves a transfer of control to the } \\
\text { learner }\end{array}$ & -1 & 4 & 0 & -1 \\
\hline 8 & $\begin{array}{l}\text { ALL involves learning from and interacting } \\
\text { with others }\end{array}$ & 4 & -3 & 1 & 4 \\
\hline 40 & $\begin{array}{l}\text { ALL involves teachers training the language } \\
\text { learners how to learn }\end{array}$ & -2 & -5 & 2 & 0 \\
\hline 32 & ALL is learner-centred learning & -2 & -1 & 3 \\
\hline 38 & $\begin{array}{l}\text { ALL involves collaboration with teachers/ } \\
\text { peers helping the learners learn the language }\end{array}$ & 5 & -2 & 0 & 5 \\
\hline 7 & $\begin{array}{l}\text { ALL is learning a language without the help of } \\
\text { a teacher }\end{array}$ & -3 & 5 & -5 & -4 \\
\hline
\end{tabular}

\section{Factor 1: Interdependence Perspective}

The participants loading on to this factor relate autonomy in language learning to interdependency within a sociological perspective. They strongly acknowledged the role context may play in improving autonomy in language learning. They view interpersonal competencies in a positive light and the collaboration between learners and teachers as significant. 
Interdependency of context, in this instance between inside and outside of classroom, is recognized as important in the development of autonomy in language learning. This is positively acknowledged with the statement "ALL takes place both inside and outside of the classroom" (S18: 5), which differs by 5 factor scores to Factor 2. The classroom, which is a more formal context with its own community that includes the teachers and peers, is seen as valuable. Nonetheless, outside of the classroom, be it within the institution or the public community at large, is of no less importance. The role that they play is significant to warrant acknowledgement. The statement which puts forward the notion that learning a language autonomously can only take place outside of the classroom (S34) appears to be considered nonsense (-4) by the participants. This is because autonomy in language learning still involves the teachers as stated in statement 38, "ALL involves collaboration with teachers and/or peers helping the learners learn the language", which is ranked as one of the highest agreed statements (5) for Factor 1.

Apart from the interdependency between inside and outside of classroom, the participants in this Factor considered the interdependency between individual and society as vital to the development of autonomous language learning. This can be interpreted from the display on the role of society / community in ALL. This is highlighted in S19, "ALL often occurs in social groups (family, clubs or community group)", one of the distinguishing statements for Factor 1. This statement (S19:2) differs by five factor scores to Factor 3 (S19: -3). The learning takes place within and from the interaction that takes place between the learners and other people around them. This is aptly shown in Statement 8, "ALL involves learning from and interacting with others", which is one of the 5 highest ranking statements for Factor 1. In addition to that, a responsible language learner, when it comes to learning autonomously, is someone who knows how to and when to act on their own and when to depend on others (S14: 4). This negotiation between the self and the social milieu (S31:2) helps the language learner to be more aware of their own role, as well as that of the community in the development of their language proficiency. Interpersonal competencies are valued highly in the development of autonomous language learning among the participants. 
Another feature of interdependency is in the collaboration between the learner and the teachers. This is seen as a positive trait and is encouraged in ALL. The participants felt that the teachers' role should remain that way as the learners strongly felt that, once the teachers start giving instructions to learners on what to do (S24: -5) and training the language learners ( $\mathrm{S} 40:-2)$, the autonomy of the learners is lost. This is further strengthened by a strong opinion (-4), disagreeing with "ALL can take place in a teacher-directed context" (S6).

This factor emphasises the need for the "learners' active participation in planning and evaluating their own learning" and this statement (S20) is ranked at 4. The planning of learning can help to highlight what the learners really need for the learning to be successful while the evaluation can give a better picture of their achievement, as well as areas for improvement. With active participation, these learners are then able to develop more effective learning strategies (S30: 2). Nonetheless, "memorising words and sentences" is not considered as to be an example of an effective learning strategy in ALL (S33: -4). When learning a language, a learner is expected to be more active in using the language, while memorising word is seen as passive endeavour.

\section{Factor 2: Empowerment and Flexibility Perspectives}

The participants loading on to this account relate autonomy in language learning to empowerment and flexibility. They identified strongly with the idea of learner centeredness, whereby the teacher has to render her authority to the students. The participants also had a positive view on the role of being flexible in order to be an autonomous language learner.

"Autonomy in language learning is learner centred" (S32: +5 ) and the participants strongly believed in this, as shown in the ranking of the statement. They, on the other hand, opposed the idea that it could "take place in a teacher-directed context" (S6: -4). What has to take place in this context is for the teacher to empower the students to have control over their learning, as stated in statement 15 , "ALL is about empowering learners to improve their conditions" $(+2)$. This idea is further supported by the statement that "Autonomy in language learning involves a transfer of control to the learner (S11: $+4)$. This empowerment is vital if autonomy is to be promoted among the learners. Some of the participants who loaded significantly 
have an even stronger opinion on this issue, i.e., that it takes more than empowerment. It needs the learner to actually undertake the learning wholly by themselves, with no assistance from the teacher. This is depicted in statement 7 that "ALL is learning a language without the help of the teacher" $(+5)$. This idea of empowerment from the teacher to the learner, a shift from some to total power, appeared to be important for these participants.

Factor 2 can also be interpreted as having a positive outlook on the idea of flexibility, as reflected in statement 26, "ALL is having the skills to be a flexible language learner" $(+1)$. Autonomous language learners have to be able to adapt the approach they use to their different needs in learning a language. The participants who loaded significantly on this factor see "communicative language learning" as not important in the development of an autonomous learner (S28: -2). The participants also appear to think that ALL does not really "involve learning from and interacting with others" (S8: -3). Communication and interaction in autonomy in language learning is reduced, and appeared less important at this particular stage of learning. They put more emphasis on other approaches to learning, including the use of self- access centres, as in statement 16: "ALL involves selfaccess language learning in the Self-Access Centre (SAC)" $(+1)$. Nonetheless, the learners need to understand that, as they progress further in their language learning and become more autonomous, the need to communicate and interact more with others may be greater, depending on their language learning goals. Flexibility is seen by the participants as the key to match the approach used to the requirements of the language learning process.

This factor also proposes that development of autonomy in language learning does not necessarily "involve using new technologies (e.g. computer-assisted language learning) (S17: -1). Neither does it "involve only the use of authentic (non- educational) materials" (4: -1$)$. Additionally, Factor 2 puts forward the idea that to become an autonomous language learner, the learners do not have to be in any specific cultural setting. This is stated in statement 39, "ALL is only applicable to Western setting" and this statement is ranked at -4 . The concept of autonomy in language learning is flexible enough that it does not require any specific kind of tools, materials or setting. 


\section{Summary and Conclusion}

The two factors revealed by the Q analysis are interpreted as Interdependence perspective and Empowerment and Flexibility perspectives. Interdependence perspective represents an important view on the involvement of the social milieu among language learners when they are practising autonomy in language learning. This social milieu could be located within the classroom, within the institution or in the community at large. The people, whether they are the teachers, peers, or parents who are available around the learners, could help these learners to develop their ability to learn autonomously. The learners' active participation is vital to Factor 1. In short, interdependency plays a vital role as interpreted in this factor.

The Empowerment and Flexibility perspectives of ALL signifies the importance of empowerment from the teacher to the learners if the learners are to develop and learn the language autonomously. This empowerment needs not be total as the learners are still trying to establish themselves as successful language learners. Apart from empowerment, factor 2 corresponds to the idea of flexibility. The tools, materials and setting are of little significance as the learners are set to develop their autonomy in language learning. What is of importance is for the learners to be able to adapt what is available to their own language learning needs.

This article has presented and discussed two varieties of perspectives deployed in the representation of Autonomy in Language Learning (ALL) among Malay trainee English teachers. It is hoped that these two perspectives would help to situate the benefit of promoting autonomy in language learning to Malaysian speakers and users of English. Thus, Autonomy in language learning is seen as a possible way in improving the English proficiency among Malaysians.

\section{References}

Benson, P., (2006). Learner Autonomy: Insider Perspectives on Autonomy in language teaching and learning. Dublin: Authentik

Benson, P., (2011). Teaching and Researching autonomy in language learning (2nd ed.). London: Pearson Education. 
Brown, S. R., (2003). Empowerment as Subjective Operant. Paper presented at the Workshop on "Measuring Empowerment: Cross-Disciplinary Perspectives" held at the World Bank in Washington D.C. on February 4 and 5, 2003.

Brown, S.R., (1993). “A Primer on Q Methodology,” Operant Subjectivity, 16: 91-138.

Dickinson, L., (1987). Self-instruction in language learning. Cambridge University Press

Exel, V. J. \& Graaf, d. G., (2005). Q Methodology: A Sneak Preview. Retrieved from: www.jobvanexel.nl.

Holec, H., (1981). Autonomy in Foreign Language Learning. Oxford: OUP

Huang, J. (2009). Autonomy, agency and identity in foreign language learning and teaching. (Doctoral dissertation, University of Hong Kong). Retrieved from: http://dx.doi.org/10.5353/th_b4175798

Oxford, R.L., (2000). Communicative strategies. In M. Byram (Ed.), Routledge Encyclopedia of Language Teaching and Learning (pp. 130-132). London: Routledge

Pemberton, R. Edward, S.L., Or, W.W.F., and Pierson, H.D., (Eds.). (1996). Taking Control: Autonomy in Language Learning. Hong Kong: Hong Kong University Press.

Pintrich, P. R., (1995). Understanding self-regulated learning. New Directions for Teaching and Learning. 63, 3-12

Stenner, P., Watts S., and Worrell M., (2008). 'Q Methodology', in Carla Willig and Wendy Stainton-Rogers (eds.), The Sage Handbook Of Qualitative Research In Psychology, (pp. 215-239).Los Angeles, CA: Sage

Wehler, T., Danielson, S., and Tule, S., (2007). Guidance on the use of Q Method for Evaluation of Public Involvement Programs in Contaminated Sites. Report Prepared Social and Environmental Research Institute, 278 Main Street, Suite 404 Greenfield, MA 01301 (413) 773-9955. Retrieved from: www.seri-us.org. 